\title{
THE EFFECTIVENESS OF IRAQI LANGUAGE WRITING PROFICIENCY ON FOREIGN LANGUAGE PERFORMANCE (ENGLISH) IN THE WRITING SKILL OF PREPARATORY SCHOOL PUPILS IN IRAQ
}

\author{
Aoda Kadhim Abid
}

Assistant Professor at College of Education for Humanities, Al Muthanna University, Iraq.

Email: khadimabid@mu.edu.iq

\author{
Article History: Received on $12^{\text {th }}$ October 2019, Revised on $29^{\text {th }}$ November 2019, Published on $19^{\text {th }}$ December 2019
}

\begin{abstract}
Purposes: This study aims at investigating the relationship between the Effectiveness of Iraqi Language Writing Proficiency on Foreign Language Performance (English) in the Writing Skill of Preparatory School Pupils in Iraq. Novelty: Despite the linguistic distance between English and Arabic, it is postulated that Arabic writing skills can be transferred positively to the target language (English).

Methodology: The researchers used the composition prompt test instrument for this purpose; one test was in Arabic and the other was in English. The population was from two preparatory schools in the general directorate of Thi-Qar. The participants were 25 male students who were chosen on the basis of the students' achievement in the previous years.

Results: That is, the participants proved to be proficient writers in Arabic after they had had a pretest in which they were asked to write a short paragraph about themselves. In conclusion, the results of the present study showed that there is no statistically significant relationship between the two languages. Those students who got high marks and were proficient in the Iraq language (Arabic) writing performed well in the counter skill (English).

Implication/Application: This result supports the theoretical views of Cummins' threshold hypothesis and Chomskian's Interdependence theory. The results of the study indicate that there is no need for integrating the instruction of writing skills between the two languages in textbooks so that the writing level of students in the foreign language (English) can be improved.
\end{abstract}

Keywords: EFL, Iraqi, Performance, Proficient, Writing.

\section{INTRODUCTION}

The transfer of skills between languages has always been the concern of many linguists and educators. For the writing skill, it is remarkable that many students of the Iraqi English Examination (an exam held by the Ministry of Education) don't even try to write property. When asked for reasons, they mostly had a typical answer, "I'm not any good at writing" or "English is not once of my good subjects". They imply that they simply do not have a talent for writing. Langan (2000) stresses that unless students change the predominant idea about writing as being "a natural talent" rather than a skill that can be acquired through learning, they will not learn how to write effectively. Langan (2000) also states that writing is a process of discovery that involves a series of steps starting by discovering a thesis often through prewriting, developing support for the thesis, organizing the thesis by making the first draft, revising and then editing to ensure an effective, error-free paper. This leads us to investigate the transfer of writing skills between the two languages (Arabic and English). Actually, it is commonly known among researchers and linguists that the similarities and differences between the two languages decide the degree and nature of transfer (positive or negative transfer). (Odlin 1989, Ellis 1986, Dweik $1986 ; 2000)$

Odlin (1989) investigated the relationship transfer between Iraqi mother tongue and foreign language and referred to the effects of both negative and positive transfer which are only determinable through comparisons of two different groups of speakers with different native languages Such comparisons often show that the cross-linguistic differences or similarities between Iraqi mother tongue and foreign language can produce negative or positive transfer. Adult EFL learners Transfer their knowledge of their Iraqi mother tongue and foreign language context. Those linguistic systems and subsystems that are transferable linguistically are the ones that play an important role in promoting foreign language skills development.

\section{Question of the Study}

The aim of the study was to discover if there was a relationship between the writing ability Iraqi language and foreignlanguage and whether the proficiency in Iraqi language writing and the degree of similarities or differences between the two languages affects the students' performance in writing. As a result, the study attempted to answer the following main question:

Is there a relationship between the writing performance and competence in the foreign language (English) and the Proficiency in Iraqi language (Arabic) among Iraqi Preparatory school pupils in Iraq.

\section{HYPOTHESIS OF THE STUDY}

The present study tried to find answers to the question raised. For this purpose, the researcher formulated the following 
hypothesis:

There is a positive relationship between the writing performance and competence in the foreign language (English) and the Proficiency in the Iraqi language (Arabic) among Iraqi fifth preparatory school pupils in Iraq.

\section{REVIEW OF LITERATURE}

\section{Theoretical Studies}

The Chomskian influence on language learning theory resulted in L2 learning being regarded as an active process where the learner consciously constructs and tests hypotheses about the target language against available linguistic data. In the Chomskian perspective, it is viewed as a critical basis for learning the new linguistic system rather than as an interfering effect. Studies in the field suggest that various linguistic elements are transferred in both the oral and written forms for 1.2 linguistic productions. For instance, elements transferred are morphosyntactic elements, communicative strategies, and pragmatics (Koda, 1988).

Cummins' (1979) threshold hypothesis postulates that a minimum level of linguistic competence in a second language must be attained in order to have a positive transfer which is also dependent upon the type of competence the learner has developed in $\mathrm{Ll}$ as proposed by Chomskian linguistic Interdependence theory. Actually, this hypothesis sheds light on this relationship. Il suggests that there may be a threshold level of linguistic competence that bilingual children must attain in order LO allow the potentially beneficial aspects of becoming bilingual to influence their cognitive growth. Cummins assumes that the bilingual aspects that influence cognitive growth arc unlikely to have an effect until the learner has attained a certain minimum threshold level of competence in a second language such as gaining the sufficient vocabulary repertoire which will enhance the learners' diction and enable them to encode and decode.

\section{Empirical Studies}

Torress and Fischer ( 1989) investigated the positive relationship. They conducted their study on Hispanic-speaking students whose overall native language proficiency IS correlated significantly with [-2 (English language) development. The study indicated that being fluent in one's native language increases the probability of becoming proficient in a second .11 also indicates that in general, Spanish speakers, English acquisition is strongly related to native-language proficiency,

On the other hand, Carson et $\mathrm{al}^{1} \mathrm{~s}$ (1990) research on the relationships between writing in $\mathrm{Ll}$ and threw some light on the possible differences among language groups. Their language groups (Japanese and Chinese students) demonstrated varying patterns with regard to transfer across languages. The writing transfer abilities were to be harder to transfer from one language to another. Carson ct al (1990) reported weak to moderate correlations between students, L1 and L2 writing scores showed a weak correlation and for the Chinese students was not significant.

\section{DATA COLLECTION}

The data was collected in the second semester of the academic year 2017 - 2018. Students were asked to write two composition prompt tests (one in Arabic and the other in English).

\section{Population and Sample of the Study}

The population or the study consisted of 50 students of fifth preparatory class aged between 16 to 17 years. The population was from two preparatory schools in the general directorate of Thi-Qar in Iraq (Al-Jumhoriya Preparatory School, Al-Yarmouk Preparatory School ). The participants were made of 25 male pupils who were chosen on the basis of of the students' achievements in the previous years. The subjects were at a high level of English performance. the number of subjects limited 25 pupils because of the students' low level and achievements in the preparatory schools in Iraq, the researcher checked back their achievements in the previous years as registered in the school records. In addition, the researcher asked the students to write a short paragraph about themselves to verify their levels (as a pretest). A pilot questionnaire was also given in which the pupils were demanded to answer the following question what makes you good in Arabic writing?

\section{INSTRUMENT OF THE STUDY}

\section{The Composition Prompt Test}

In this study, a composition prompt test was used as an instrument to assess Arabic and English writing. The composition prompt is similar to the instrument used by Carson et al ( 1990 ), two topics, one in Arabic and the other in English were chosen and they were suitable to the students' levels and appealing to the students' common knowledge so that the students would demonstrate interest while writing about the topics. In other words, the researcher took into consideration that the students were familiar with the topics and the topics are chosen were relevant to students' social life. The Arabic topic required the students to discuss their preferences about living in the city or the countryside: Do you prefer to live in the city or the countryside? Discuss the advantages and disadvantages. The English topic required the students to describe marriage traditions in their country: describe the marriage traditions in your country (how a couple gets married). 
In the construction of' the prompt test, the researcher adhered to the rules and criteria of the TOEFL test for written English (TWE), which uses composition prompts. Similar rating criteria were used in the Arabic composition. The criteria used were based on the one used by the Committee of Education of the general directorate of Thi-Qar.

1. Did the students appropriately respond to the prompt or did they deviate?

2. Did the students organize their ideas well'? And how logical was the progression or these ideas?

3. Were the structures sophisticated and accurate?

4. Did the students choose suitable vocabulary to express their ideas'?

5. Did the students use accurate punctuation, spelling and other writing considerations?

6. Did the students use accurate paragraphing?

7. Did the students use classical or standard Arabic? Or did they use colloquial Arabic?

Although the instructions were available and easy to follow, both the researcher and the teachers went over the exams again and again. They discussed the instructions and the ways these tests would be conducted.

Warriner's (1986, P438) guidelines were used in correcting the English composition prompts:

1. Did the paragraph have a topic sentence that clearly states the paragraph's main idea and arouses the reader's interest?

2. Were the structures, vocabularies, punctuation, and spelling accurate?

3. Did the supporting sentences develop the paragraph's main idea with sufficient detail?

4. Would the paragraph be improved by adding a clincher, or a concluding sentence that restates the main idea, summarizes specific details, or suggests a course of action?

5. Did every sentence in the paragraph directly relate to the main idea? I lave all sentences that destroy the paragraph' unity been eliminated?

6. Were the ideas in the paragraphs arranged logically according to a definite plan'?

7. Did the paragraph contain pronouns and transitional expressions that link ideas clearly to one another and make the paragraphs easy to follow?

\section{RESULTS OF THE STUDY}

The results of' the study is presented with respect to the research question:

"Is there a relationship between the writing performance and competence in the foreign language (English) and the Proficiency in Iraqi language (Arabic) among Iraqi preparatory school pupils in Iraq?

The analysis of data was conducted in order to investigate the issue of correlation between English writing skills with the same skills in the Arabic language. The researcher used Pearson's analysis tests. The analysis produced a correlation between the two tests. The correlation coefficient (r) was used to measure the relationship. This analysis was aimed at verifying the nature of the transfer of the writing skill from the Iraqi language to a foreign language. In other words, this study was designed in such a way to determine whether the achievement in writing in the (English) is affected by the level of' achievement in the Iraqi language (Arabic) (as proposed by Chomskian Interdependence theory) and the competence in foreign language (English) (as proposed by Cummins' Hypothesis).

The study question addressed the relationship between writing in the English language and the same skill in the Arabic language. The study revealed that there is no statistically significant relationship between the students' proficiency in Arabic writing and English writing. The scores of the two tests revealed this correlation (as shown $\mathrm{n}$ in Table 3).

Table 1: The Raw Scores of the English and Arabic Tests

\begin{tabular}{ccc}
\hline Subject No. & English Composition & Arabic Composition \\
\hline 1 & 78 & 64 \\
\hline 2 & 69 & 70 \\
\hline 3 & 64 & 69 \\
\hline 4 & 69 & 66 \\
\hline 5 & 66 & 65 \\
\hline 6 & 71 & 78 \\
\hline 7 & 59 & 70 \\
\hline 8 & 54 & 64 \\
\hline 9 & 56 & 64 \\
\hline 10 & 78 & 71 \\
\hline
\end{tabular}




\begin{tabular}{ccc}
\hline 11 & 68 & 87 \\
\hline 12 & 72 & 70 \\
\hline 13 & 80 & 81 \\
\hline 14 & 65 & 73 \\
\hline 15 & 71 & 63 \\
\hline 16 & 65 & 60 \\
\hline 17 & 71 & 67 \\
\hline 18 & 73 & 64 \\
\hline 20 & 67 & 70 \\
\hline 21 & 53 & 66 \\
\hline 22 & 60 & 67 \\
\hline 23 & 74 & 75 \\
\hline 24 & 81 & 83 \\
\hline 25 & 87 & 79 \\
\hline Score's range & 71 & 71 \\
\hline & 25 & 25 \\
\hline Total No. of subjects & 68.88 & 70.28 \\
\hline
\end{tabular}

Total: 69.5

In addition, the statistical analysis in Tables 2 and 3 displays a correlation between English and Arabic writing skill results.

Table 2: Means and Standard Deviations for the Tests

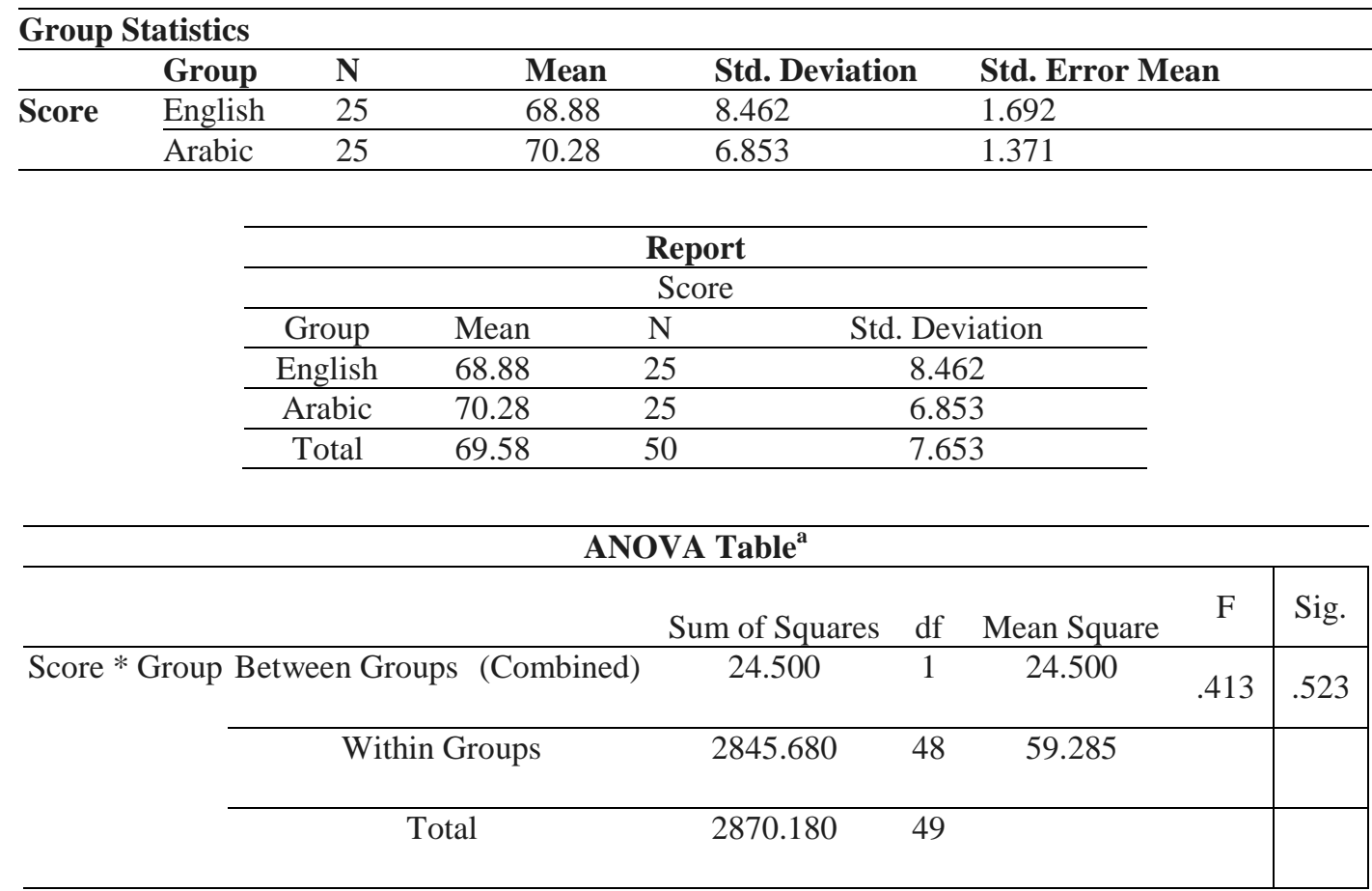

a. With fewer than three groups, linearity measures for Score * Group cannot be computed.

From Table 2 we can notice:

The analysis of' the raw scores showed the means: 68.88 for Arabic and 70.28 for English, standard deviations: 8.462 for Arabic and 6.853 for English. The number of study subjects was 25 students for Arabic and 25 for English, but the number was changed due to 10 correlation techniques' procedures,

Table 3: Correlative Coefficients for the Arabic and English Tests

\begin{tabular}{cccc}
\hline \multicolumn{3}{c}{ Correlations } \\
\hline \multirow{3}{*}{ Group } & Group & Score \\
\cline { 2 - 4 } & Pearson Correlation & 1 & .092 \\
\cline { 2 - 4 } & $\begin{array}{c}\text { Sig. (2-tailed) } \\
\text { Sum of Squares and Cross- } \\
\text { products }\end{array}$ & 12.500 & .523 \\
\cline { 2 - 4 } & Covariance & .255 & .357 \\
\hline
\end{tabular}




\begin{tabular}{cccc}
\hline & $\mathrm{N}$ & 50 & 50 \\
\hline Score & Pearson Correlation & .092 & 1 \\
\cline { 2 - 4 } & Sig. (2-tailed) & .523 & \\
\cline { 2 - 4 } & $\begin{array}{c}\text { Sum of Squares and Cross- } \\
\text { products }\end{array}$ & 17.500 & 2870.180 \\
\cline { 2 - 4 } & Covariance & .357 & 58.575 \\
\cline { 2 - 3 } & $\mathrm{N}$ & 50 & 50 \\
\hline
\end{tabular}

From Table 3 we can notice

Table 3 is a simplified summary of the correlation (correlation coefficient) It shows that the Arabic composition and English composition have the same correlation coefficient (r) 58.575 in the two tests' results. The researcher made use of the composition prompt tests' correlation in Table 3 which revealed that the two writing skills had the same correlation and that was obvious from the students' scores.

By examining the students' scores it 'Was noticeable that students who got high marks in Arabic obtained very close marks in English (see the high scores of the study subjects in Table 1).

From the results shown in the three tables, we conclude the following:

1. The correlation coefficients for the two tests' results revealed the significant relationship between Arabic and English writing.

2. The analysis of the English composition (English writing skill) and the Arabic composition revealed the correlation, This relationship indicated that the Arabic composition (Arabic writing skill) and the English composition (English writing skill) had the same correlation coefficient $(r)=0.092$.

\section{CONCLUSIONS}

The correlation found between English and Arabic writing implies that students who were good Arabic writers do not transfer their knowledge to English writing which attests to Cummins' hypothesis and Chomskian interdependence theory. This result requires EFL planners and curricula developers to study Arabic composition to identify its relationship to English composition. Before EFL instructors start teaching English composition, they need to examine Arabic composition to acquaint themselves with students' strengths and weaknesses in order to compare and contrast their later EFL development.

This testifies no need for integrating the instruction of the two languages in ESL textbooks. There is no need for integration between the two languages which makes the textbooks pedagogically sounder and more meaningful. In other words, in order to ensure good writing competence, we should take into account teaching it alongside Arabic in terms of leaching the writing strategies.

\section{REFERENCES}

1. Canale, M., Frentte, N., \& Belanger, NI. ( 1988). Evaluation Of minority students in first and second language. In J. Finc (Ed.), Second Language Iiscourse (pp. 83-95). Norwood, N.I: Ablex.

2. Carson, J., Carrel], P Silberstein, S., K roll, B., Kuehn, P (1990). Reading - writing relationships in first and second language. TESOL . Quarterly, 24, 245-263. https://doi.org/10.2307/3586901

3. Dweik, B. (2000) Bilingualism and the problem of linguistic and cultural interference. In: Alharbi, L. and Azer, H. [n: Arabic Language and Culture a Borderless World. Kuwait University.

4. Koda, K. (1988) Cognitive process in second language reading: transfer of LI reading skill and strategies. Second Language Research. 4, 1 39-146 Langan, J. (2000) College Writing Skills. Edition. Atlantic Community College, McGraw. https://doi.org/10.1177/026765838800400203

5. Langan, J. (2000) College writing skills. $5^{\text {th }}$ Edition. Atlantic Community College, McGraw Hill .

6. Odlin (1989) Language Transfer-Cross Linguistic Influence in Language Learning. Cambridge University Press, Michael H. \& Richards, J. (Eds.). https://doi.org/10.1017/CB09781139524537

7. Torres, J., \& Fischer, S, (1989). Native Language Proficiency as Predictor of LEP .Students' Growth in English . Unpublished manuscript. ERICED 310-632.

8. Warriner, 1. (1986) Warriner's English Grammar and Composition. Liberty edition. HBJ publishers. Orlando, San Diego, Chicago, Dalla

9. Mutar, Q. M., \& Nimehchisalem, V. (2017). The Effect of Gender and Proficiency Level on Writing Strategy Use among Iraqi High School Students. https://doi.org/10.24093/awej/vol8no2.12

10. Ghanim, I. R., \& Khalaf, O. N. (2012). Using Cued-Dialogue And Gap Filling Exercises To Develop Iraqi Efl Learners'ability Of Speaking. Al-Fatih Journal, 8(50), 1-21.

11. Jameel, A. S., \& Mohamood, D. F. (2017). The effect of flexibility and fluency strategies on developing creative writing skills in English language subject of the fourth preparatory literary students. International Journal of Humanities and Applied Social Science, 2(1), 37-50. 
12. Kavlu, A. (2017). Implementation of Project-Based Learning (PBL) in EFL (English as a Foreign Language) classrooms in Fezalar Educational Institutions (Iraq). In 5th International Research Conference on Education, May 1-2, Tbilisi, Georgia. https://doi.org/10.23918/ijsses.v4i2sip67

13. Ahmed, H. A. (1989). The role of attitudes and motivation in teaching and learning foreign languages: a theoretical and empirical investigation into the teaching and learning of English in Iraqi preparatory schools.

14. Ulker, V. Impact of the Alignment between Learning Outcomes and Assessment on English as a Foreign Language Students' Writing Skills Development (Ishik University Language Preparatory School Case).

15. Celik, B. C. (2019). Relationship between Foreign Language Learning and Exam Stress with Gender: A Study on Tshik International University Preparatory School Students, Iraq. International Journal of Social Sciences \& Educational Studies, 5(3), 311-322. https://doi.org/10.23918/ijsses.v5i3p311

16. Al Tuhafi, H. (2003). A narrative inquiry: Iraqi secondary teachers of English experiences with Communicative Language Teaching (CLT) approach in Iraq. English Language Teaching, 2(2).

17. Mahdi Mutar, Q., \& Nimehchisalem, V. (2017). The Effect of Gender and Proficiency Level on Writing Strategy Use Among Iraqi High School Students. Arab World English Journal (AWEJ) Volume, 8. https://doi.org/10.24093/awej/vol8no2.12

18. HamsaKadhumTaha, A. P. S. S. S. (2017). The Impact of Number Head Together Technique on Iraq EFL Students' Performance in Reading Comprehension. journal of the college of basic education, 23(97/-109 انساني), 126.

19. Al-Noori, B. S. M., \& Al-Mosawi, F. R. A. H. (2017). Investigating Iraqi EFL College Students' Attitude towards Using Cooperative Learning Approach in Developing Reading Comprehension Skill. Journal of Language Teaching and Research, 8(6), 1073-1080. https://doi.org/10.17507/j1tr.0806.07

20. Majeed, N. T. (2016). The Effect of Self-Assessment as a Revision Technique on Preparatory School Students' Achievement in Writing English. BOOK OF PROCEEDING, 399. 